\title{
The Role of Education in Fostering Peace and Unity in Nigeria Between 1914 and 1938
}

\author{
Hannah Okediji \\ Ministry of Education, Secretariat, Ibadan, Oyo State, Nigeria
}

\begin{abstract}
As the world marks the centenary of the outbreak of the First World War and Nigeria celebrates the centenary of the amalgamation of the northern and southern Protectorates of 1st January 1914, when Nigeria became a nation, it is pertinent to examine the contribution of education to fostering peace and unity in the post War era in Nigeria, from 1914 to 1938. Through historical research this project analyzes primary and secondary sources such as journals, publications, textbooks and internet materials. The findings of the study revealed that Nigeria, like other participating British colonial territories felt the impact of the First World which began in Europe in 1914 and ended in 1918. Much of the fighting took place among the central powers. In 1917, the USA joined the war against Germany as a consequence of her submarine activities and intrigues in Mexico. The War had a negative political, economic and social impact on all nations, leading to the peace conference in Paris and the treaty of Versailles in June 1919. Nigeria played a very vital role in the drive to achieve this by providing military training as well as a training in citizenship for democracy and political leadership. A culture of peace, education and non-violence has been the norm in Nigeria since the post-war period. The aims of the paper therefore are to understand the state and the role of education during the war and post-war period in Nigeria, to analyze the role of education in fostering peace in the education and to recommend ways of maintaining peace in the education sector in Nigeria. It is therefore recommended in this paper that the Nigerian Educational Research Development Council, should formulate policies that will bring cohesion with a bid to balancing the gap between the North and the South, that Labour Unions should resolve issues with government on a round table conference and not through violence and strike actions i.e. the Nigeria Union of Teachers, government should not mix educational matter with politics and education personnel should be well remunerated and given maximum encouragement to enhance productivity in the sector.
\end{abstract}

Keywords: role, education, development, fostering, peace, unity

\section{Introduction}

Education is a process of systematic institutionalized transmission of knowledge and skills as well as basic values and norms that are acceptable in a particular society. The concept of peace is defined as the process by which conflict, chaos, disputes or differences are resolved among two individuals, or groups of people or from one nation to another. There is a difference between positive and negative peace. Positive peace involves the 
development of a society in which except for the absence of direct violence, there is no structural violence or social injustice while negative peace is the absence of large scale physical violence, that is, the absence of condition of war. It could therefore be rightly said that, education geared towards forestalling, peace could be referred to, as peace education.

Peace education could be defined as an interdisciplinary area of education whose goal is non-institutionalized teaching about peace and for peace. The aim of peace education is to assist students to acquire skills for non-violent conflicts resolution and to reinforce these skills for promotion of the values of peace. It is important to stress here that unlike conflict resolution which is retroactive, that is trying to solve a conflict after it has already occurred. Peace education has a more proactive approach. Its aim is to prevent a conflict in advance or rather to educate individuals and societies for a peace tolerance, unity, equality, respect for individual and societal differences and social justice.

The understanding of the concept of peace and unity has increased tremendously in Nigeria through history, the end of the first world war brought powerful support for the need for international cooperation and understanding which helped to instill a desire to include these ideas in the educational system. The League of Nations and a number of non-governmental organizations worked together on these ideas.

The focuses of this paper therefore are to understand the historical background of the first world war, identify the effect of the war and the state of education within the period of study, analyze the role of education in fostering peace and unity in Nigeria and other nations between the first and the second world wars and offer recommendations for maintaining peace and unity in the education sector in Nigeria.

\section{Objectives of the Paper}

The following are the objectives of the paper:

- to identify the historical background of the first world war;

- to understand the effect of the first world war and the state of education in Nigeria between 1914 and 1938;

- to analyze the role of education in fostering peace and unity between the first and second world war;

- to offer suggestions for maintaining peace and unity in the education sector in Nigeria.

\section{Research Questions}

The following research questions are raised for this paper:

- What was the historical background of the First World War?

- What were the effect of the First World War (WWI) and state of education in Nigeria between 1914 and 1938 ?

- What were the role of education in fostering peace and unity between the first and Second World War in Nigeria?

-What are the suggestions for maintaining peace and unity in the education sector in Nigeria? 


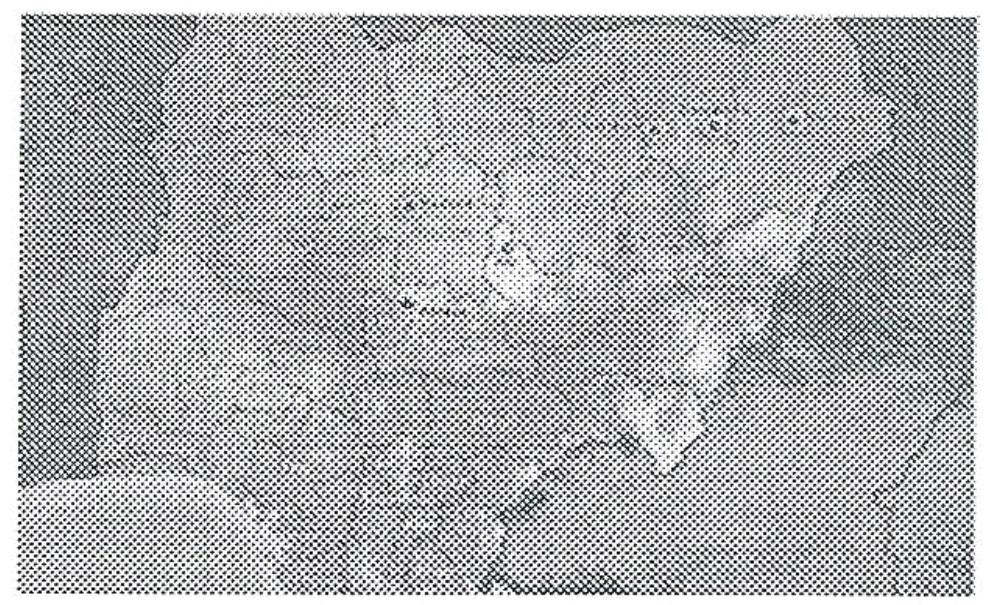

Amalgamation of Nigeria | Religion map.

\section{Historical Background of the First World War 1914-1918}

The First World War was prompted by the revolutionary communist in Russia led by Lenin the Bolshevik leader on the morning of 7th November, 1917. The operation started at the Simony Institute, a fashionable girls school. By the evening of that day Tsar Winter palace in Russia was taken over by the Bolshevik.

According to Watson (1974), The first world war began in Europe in 1914, developing out of the quarrels of Europeans, and it remained predominantly Europeans. Most of the fighting took place in Europe where the central powers (Germany, Austria-Hungary and their allies) were locked in conflict with Britain, France, Russia and their allies. Many of the European states possessed great overseas empires and these too were inevitably caught up in the struggle. So too was Japan bound to Britain by the alliance of 1902, the war thus sprained like a plague across the world, reaching into Africa, the middle east and the far east and dragging in combatants from India and Australasia.

The USA joined the war against Germany in 1917 angered by the activities of German submarines and German intrigues in Mexico but Americans regarded it as a war to besettled "over there" that is Europe.

The first world war came to an end by armistice at the eleventh hour of 11th November, 1918. Germany went to war in August 1914 and Prime Minister Andrew Fisher's government pledged full support for Britain. The outbreak of the war was greeted in Australia as in many other places with great enthusiasm.

Australia's early involvement in the great war included the Australian Naval and military expeditionary force landing at Rabaul on 11 September 1914 and taking possession of German New Guinea, at Tema on 17th September 1914 and the neighboring Islands at the Bismarck Archipelago. In October 1914, the Royal Australian Navy made a significant contribution when the HMAS Sydney destroyed the German raider SMS Emden.

On 25 April 1915 members of the Australian imperial force landed at Gallipoli; together with troops from New Zealand, Britain and France. Throughout 1916 and 1917 losses on the Western front where heavy and gains were small. In 1918 the Australians reached the peak of their fighting performance in the battle of Hamel on 4th July for Australia as for many nations, the first world war remains the most costly conflict in terms of deaths and casualties from a population of fewer than five million, four hundred and sixteen thousand eight hundred and nine 
$(416,809)$ men enlisted of which over fifty thousand $(50,000)$ were killed and one hundred and fifty six thousand $(156,000)$ wounded, gassed or taken as prisoners.

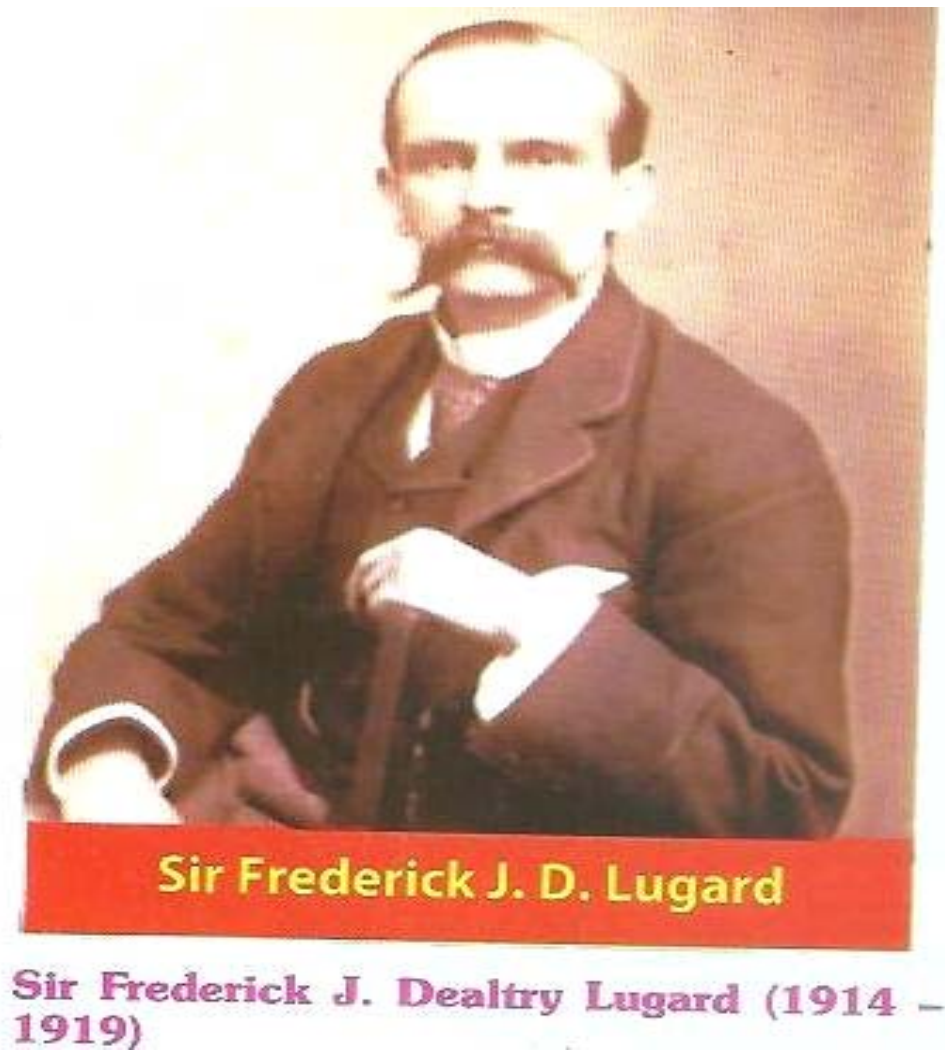

Father of the Nigeria Amalgamation

\section{Causes of First World War 1914-1918}

Germany, France, Russia, Australia, Hungary and Britain attempting to keep the lid on the simmering Cauldron of Imperialist and Nationalist tension in the Balkan to prevent a general European War. They were successful in 1912 and 1913 but did not succeed in 1914.

The main causes of World War I which began in central Europe in late July 1914 included many factors such as:

- the conflict and hostility between the great European powers of the four decades leading up to the War;

- militarism alliances;

- imperialism and nationalism.

The immediate cause of the War lay in the decision taken by statesmen and generals during the July crisis of 1914 caused by the assassination of Archduke Franz Ferdinand and his wife Sophie by Gautilo Princio irredentist Serb and member of the Serbian Nationalist Organization, The Back Hand, the crisis came after a long and difficult series of diplomatic clashes between the Great powers (Italy, France, Germany, Britain, Austria, Hungary, and Russia over European and Colonial issues in the decades before 1914 that had left tension high. In turn these diplomatic clashes can be traced to changes in the balance of power in Europe since 1867. The more immediate cause of the War was tension over territory in the Balkans. It was caused by the great and central 
powers of the world. It was also caused by a discontentment among citizens who were trapped down in the Austria Hungary Empire and Turkey.

The following represent the pictures of the colonial administrators within the period of study:

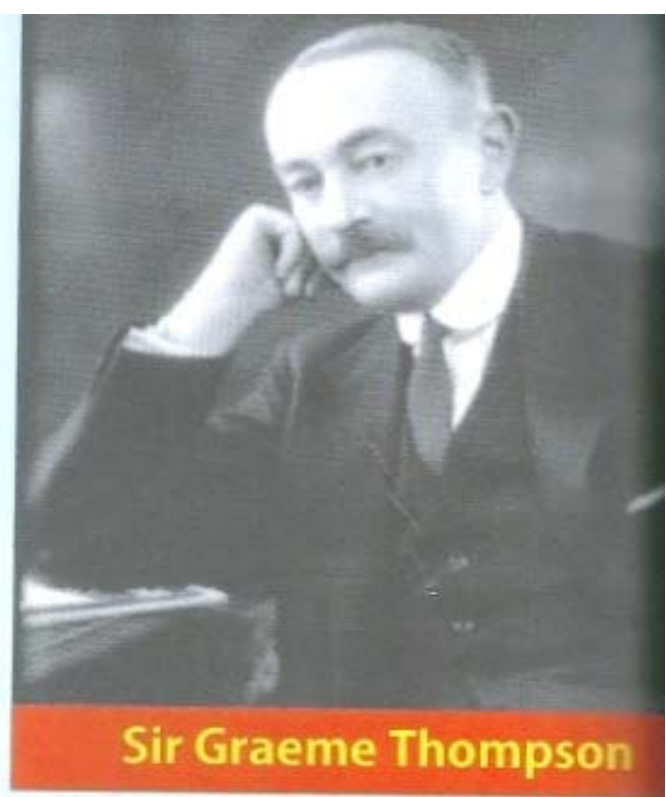

Sir Graeme Thompson (1925-1931)

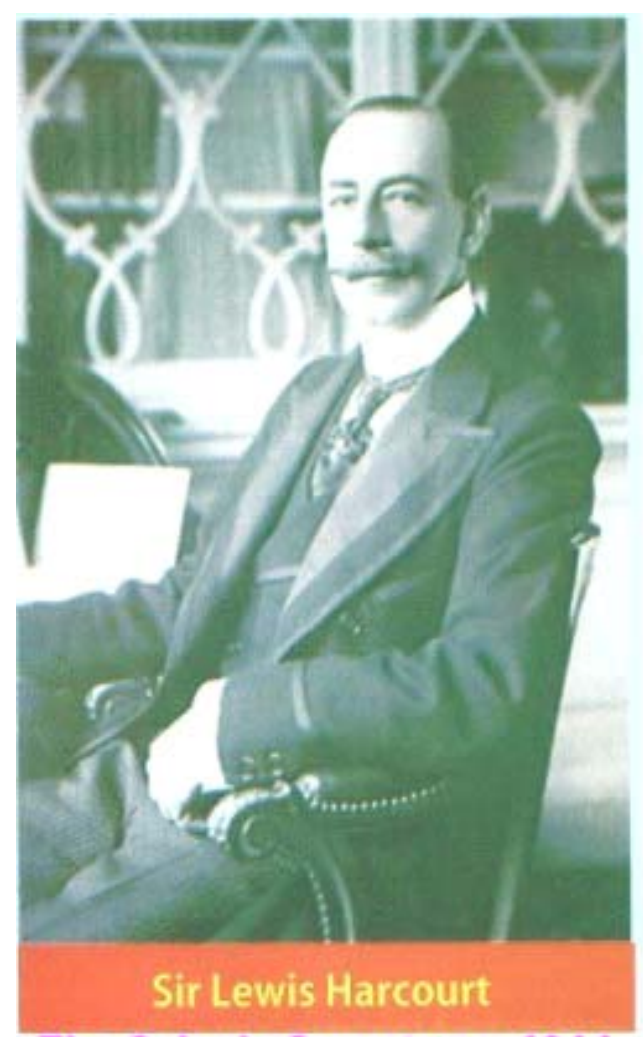

The Colonia Secretary - 1914

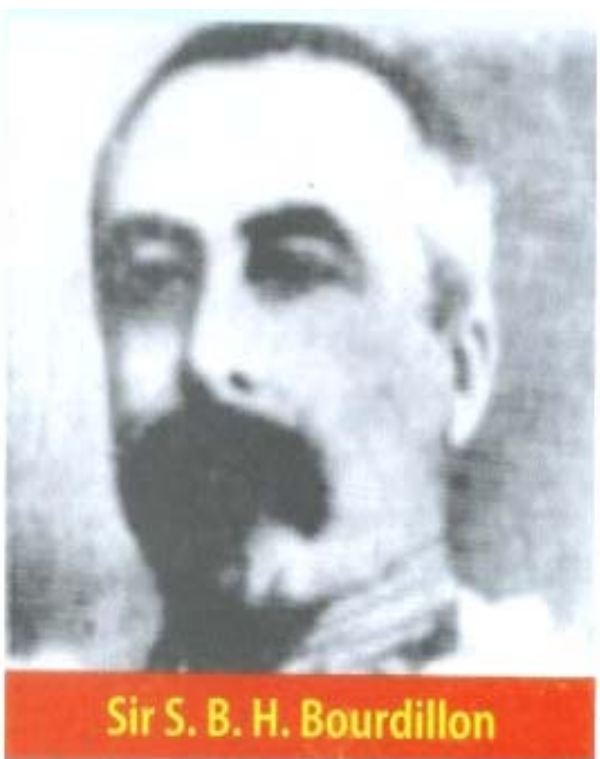

Sir Bernard Henry Bourdillon (1935 1943)

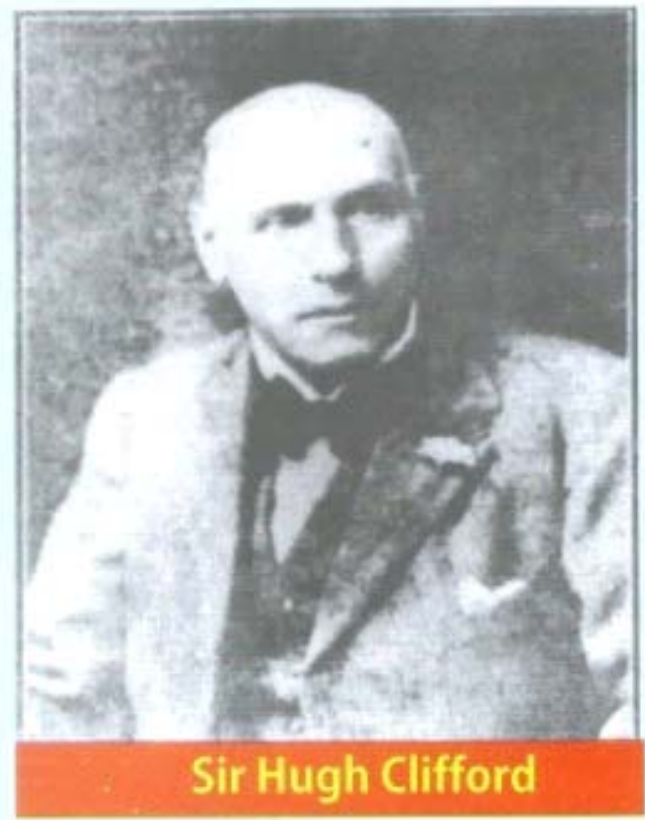

Sir Hugh Clifford (1919 - 1925) 


\section{The Effect of the First World War on Education and the State of Education in Nigeria Between 1914 and 1938}

The First World War had devastating effects on Nigeria like any other nation of the world. After the World War I, the peace settlements among the great powers and the central powers i.e. peace conference of Paris, league of nation and treaty of Versailles had certain clauses which allowed for scramble for Africa and overseas territories for protection or in other words to impose their power over those countries to become their colonies or protectorates. The enthusiasm of Britain as one of the victors of the war made her to establish a protectorate over Nigeria in 1900, through a tripartite form of administrations (the colony of Lagos, Southern protectorate and Northern protectorate). The three political administrations was eventually amalgamated in January 1st 1914, when Nigeria became a unified nation under one umbrella with Sir Fredrick Lord Lugard a British ex-soldier at helms of affairs of the Governor General.

According to Oduwobi (2011) ... in 1900 political control was formerly established over the Nigerian area, it took the tripartite form of three autonomous administrations these three became subsequently amalgamated in 1914 to form the Nigerian State.

The state of education therefore in Nigeria at the outbreak of the First World War 1914 was that of an imposed British type of education a situation where the British imposed their own culture, language and aspiration to become world overlord on the instructions given to Nigerians in the school. So educationally Nigerian education was colonized by the British life style and culture.

Education brought little progress during the colonial administration of Sir Donald Cameron 1931 to 1935. According to Aderemi (2013):

Sir Donald Cameron became the fourth expatriate Chief Administrator of Nigeria in 1931 with the departure of Sir Graeme Thompson, Great strides were achieved during his tenure especially in the field of education ... On January 22, 1932, the first private proprietary Secondary School in Nigeria was established at Ile-Ife by the Ooni of Ife, barely one year on the throne. The School, Oduduwa College came about four months before Alvan Ikoku established the Aggrey Memorial Grammar School Arochukwu on April 4.

On January 19, 1934, Sir Donald performed the official opening of the Yaba Higher College, the first tertiary institution in Nigeria and the college that gave Nigeria its first set of licentiate doctors and pharmacists. The College admitted students in December 1933 to study Medicine, Engineering, Pharmacy and Education courses to provide middle level manpower for the emerging nation. However, the Yaba Higher College that provided the first set of students that were pioneers in the new University Grade College, University College, Ibadan (UCI) a College of the University of Londons.

There was the negative effect of indirect rule system of administration on social, educational, economic and political life of Nigerians between the two world wars. The Governor-General, Fredrick Lord Lugard applied the territorial divisions of the northern part. This style of administration affected education and other sectors badly, because the interest, levels of intelligence and culture of the Hausas and Fulani's in the north are quite different from those of the Yoruba's and Igbo's in the South. The policy on education, education ordinances and education laws made could not work to promote education for the different ethnic groups. 
Economically, the regular imposition of taxation was not acceptable among the Yorubas in the south and therefore met with opposition in 1918. For the opposition, that could not be introduced among the Igbo people in the South Eastern part until 1928.

Politically, the concept of paramount authority caused confusion and conflict for British overlord. The Native Authority Ordinance created problem in the Yoruba land because the traditional leaders were not given due recognition, in the South Eastern part. The issue of warrant chiefs caused riots in Warri and Aba in 1927 and 1929 respectively, on the issue of taxation this situation led to cancellation of Native Authority Ordinance and warrant chief system in the 1930s.

The period between 1914 and 1924 experienced an intensive missionary activities, wherein various missions like the Roman Catholic, Qua Iboe, Primitive Methodist Missionary society etc. took the advantage of the establishment of British Government after world war I, to spread the gospel and also established few schools. However there was no clear cut direction for the educational system in Nigeria during this period up till 1925. Osokoya (2010) commented on this and said up till 1925, the British government had no clearly defined policy on Education for its African colonies. Prior to this time laissez faire was the order of the day and the local administration in consultation with the local christian mission and officers managed the educational enterprise as best as they could

The missionary activities aimed at spiritual conversion of souls after world war I in establishing the schools without definite policy on education. The Phelps stokes Commission's report of 1922 titled "Education in Africa" brought a new light to Nigerian education, because it condemned the type of education offered Africans especially Nigerians by the British indirect system of government, that the education was tailored after the prevailing situation in Britain not after meeting the interests aspirations and needs of Nigerian's it then demanded for a system of education based on Nigerian culture. Osokoya (2002) in Osokoya (2010) corroborated this and said, "The report therefore made proposals for the development of education along the vocational and agricultural lines, and the establishment of farm demonstration schools, particularly in rural areas among other recommendations."

Therefore Phelps stokes commission's report laid a solid foundation for the colonial policy on education in Nigeria within the period of study 1914 to 1938. The outcome of the report gave birth to 1925 educational memorandum; the recommendations of the report impacted so much on educational policies, practices and guidelines in Nigeria. It also served as reference point for missions to assess Nigerian educational needs and to develop educational curriculum in the areas of educational objectives, relevance of education, local languages girls and women education.

Conclusively, the period between 1914 and 1938 was a period when the education in Nigeria suffered ship-wreak, through an imposed system of colonial administration which failed to carry along the interest of their subject (i.e. Nigerians) along. Also within the period a clear cut direction and good foundation was laid for the formulation of the current day educational curriculum because of Phelps—stokes commission's report of 1922.

The picture following represented the Nigerian nationalist leaders who fought for independence peace, unity and the development of education in Nigeria from the colonial era to post independence period. 


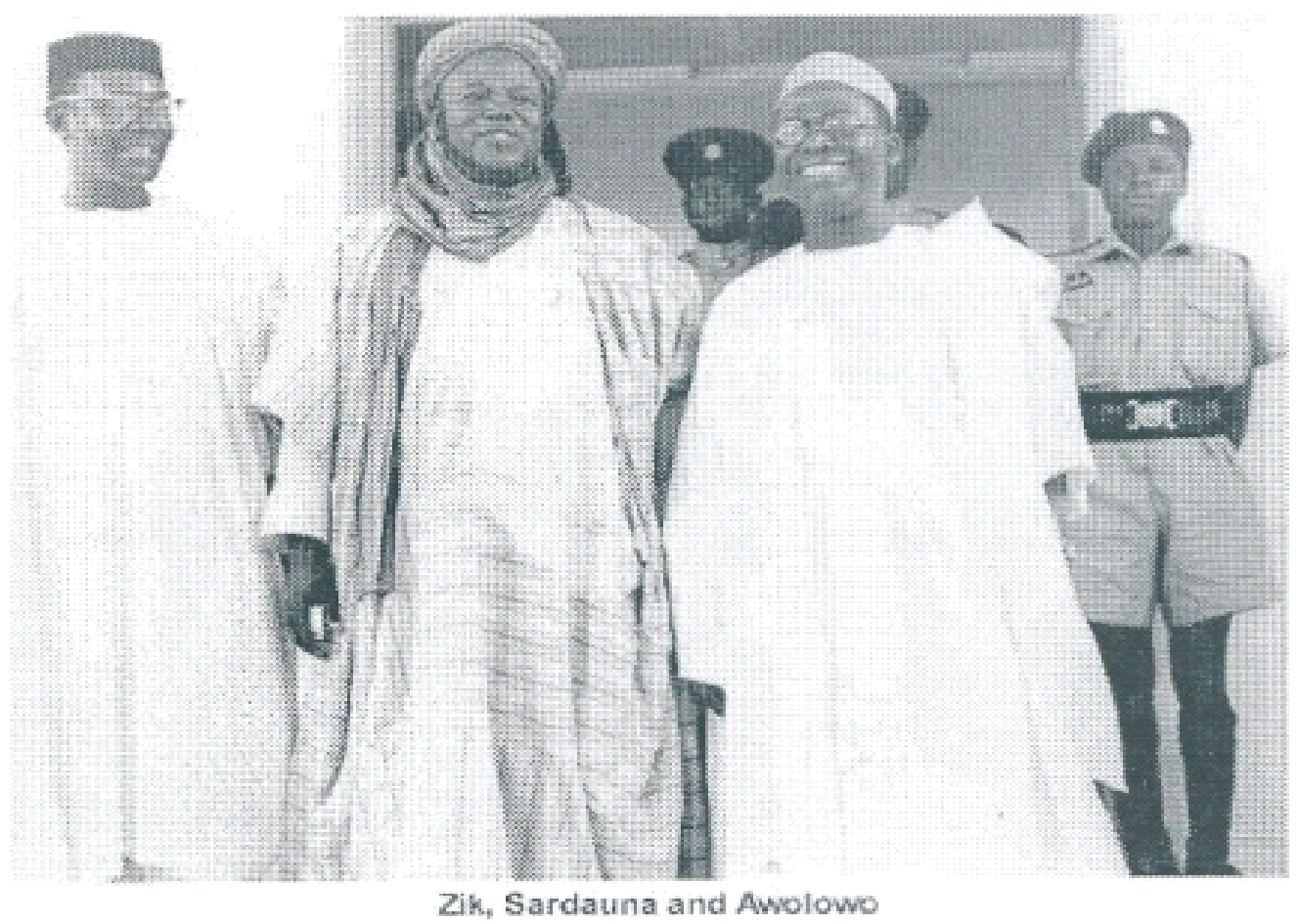

\section{The Role of Education in Fostering Peace and Unity in Nigeria Between 1914 and 1938}

According to a peace education writer "Education is the instrument for uniting kingdoms or nations, bringing human beings closely together". In many parts of the world civil society suffers because of the situation of violent conflicts and wars. It now becomes necessary to recognize the crucial role of education in building a culture of peace, unity and condemning a situation where education is undermined in order to attack democracy and tolerance.

A culture of peace and non-violence has been a norm and practice in Nigeria since pre first world war period and continued till date. This culture advocates for fundamental human rights, social justice, democracy, literacy, respect and dignity for all, international solidarity, respect for the right of workers, right of children, gender equality, cultural identity, indigenous peoples minorities rights and preservation of the natural environment.

Education is a key tool in combating poverty, in promoting peace, social justice, human rights, democracy, cultural diversity and environmental awareness, education for peace implies an active concept of peace through values, life skills and knowledge in a spirit of quality, respect. Empathy, understanding and mutual appreciation among individuals, groups and nations.

"The educational action for promoting the concept of peace concerns the contents of education and training, educational resource and material, school and university life, initial and ongoing training for teachers, research, and ongoing training for young people and adults.” A culture of peace must take root in the classroom from an early age. It must continue to reflect in the curricula at secondary and tertiary education. More still the skills for peace and non—violence can only be learned and perfected through practice. 
Active listening, dialogue, mediation and co-operative learning are delicate skills to develop. This is education in the widest sense; it is a dynamic, long term process, a life time experience. It involves providing both children and adults with an understanding of and respect for universal values and rights it requires participation at all levels, family school, places of works, news rooms, playgrounds, and the community as well as nation.

Peace education are taught in the school lessons to involve relevance to the immediate environment empowering individuals to achieve a just society in which all human rights of every citizen is valued and respected. This is in line with the Nigerian education philosophy and objectives which states that "2,000-year of culture of peace and Olympic truce manifesto was developed for the above teaching violence in schools woman involvement in peace building policy.” The culture of peace was extended to all learners including refuges of war and immigrants children, children of minorities and disabled with the objectives of promoting equal opportunities through education.

According to Oduwobi (2011) the Nationalist movement rose up against the colonial imperialism and oppressive ambition by the end of the 1930s and 1940s while the western educated Nigerians agitated against the ills of indirect rule.

Oduwobi (2011) stated thus on colonial imperialism in Nigeria:

One of the assumptions underlying the imposition of colonialism was the notion of white supremacy. Accordingly, the colonial situation was characterized by racial inequality and discrimination. A policy of separativeness was maintained in all spheres of social life thus, for example, not only was Europeans settled in different residential areas, their quarters contrasted sharply with the squalor of the Nigerian areas as there was a wide disparity in the quality and quantity of the provision of facilities again job opportunities and promotion for Nigerians were limited. Few Nigerians attained the upper echelons in both government and private organizations, and even then these ones did not enjoy equal level of emoluments and perquisites with their European colleagues fostered by the early Christian missionaries who felt that Nigerian did not have much worthwhile heritage and so denationalized them.

This provoked the educated Nigerians who were products of the mission schools. Through this agitation for restoration of African cultural heritages, cultural nationalists like Obafemi Awolowo from the west, Nnamdi Azikwe from the east and Sadauna from the north were able to retain some of the Nigerian heritages and fostered peace and unity at home.

The educated Nigerians also fought against economic exploitation in order to maintain peace and unity, this is because by 1930, the British had dominated both the internal and external trade in Nigeria through Europeans Firms like UAC, CFAO, and PZ etc. who dictated the prices of goods.

The Nationalists also fought for peace and unity along educational line in that provision of education was centralized on the christian mission. The mission's main target was conversion of souls, they were also limited by finances to extend education opportunities to all citizens. This did not allow for the growth of higher institutions to develop higher manpower.

Labor unions have been a part of Nigerian industry since 1912, when government employees formed a civil service union in 1914, this organization became the Nigerian union of civil servants after the merging of the protectorates of Northern Nigeria and Southern Nigeria. In 1931 two other major unions were founded the Nigeria Railway Workers Union and the Nigeria Union of Teachers (which included private School Teachers). Legalization of unions in 1938 was followed by rapid labor organization during world war II as a result of 
passage by the British government of the colonial development and welfare Act of 1940 which encouraged the establishment of unions in the colonies.

Women equally used their traditional, economic or political education in fostering peace and unity in Nigeria within the period of study, this had immense and direct influence on the family lives, work ethnics, politics and social relationship in the Nigerian society. According to Richard Reid (2014) commenting on the roles of Nigerian women, said, "with other aspects of society woman's roles were primarily governed by regional and ethnic differences.” In the North Islamic practices were still common. This process meant generally, less formal education early teenage marriages, especially in rural areas, and confinement to the household which was often polygynous, except for visits to kin ceremonies and the work place if employment were available and permitted by a girl's family or husband.

Women in Hausaland did not work in the fields but Kanuri women were working in the fields. In general in the Nigerian society more women got engaged in harvesting, household work child bearing and rearing, while only few women were engaged in professions like bank, teaching, medicine etc.

Consequently a medical School was established, in 1930 Yaba Higher College was established in 1934. But this had their limitations as they were denied to have University status and the government policy did not permit the institution to train high level manpower skills because there were no courses in humanities and social sciences. The students graduated with diploma certificates which only fetched them subordinate position in the labor market. Nigerians educated elites protested against this and formed the Lagos Youth Movement in 1934. The group changed its name in 1936 to Nigerian Youth Movement in order to identify with national issues of unity and peace at home

Politically the educated Nigerian Nationalist fought for national unity and peace on the issue of self determination which excluded Nigerians. The nationalists argued that their recruitment in the British army in preparation for the Second World War would not bring any gain to them because all hope to gain independence at the end of the war would not be realized.

Also the constitutional provision since amalgamation in January 1914 which gave room for less Nigerian involvement in governance was agitated against. According to Oduwobi (2011) "The amalgamation of the country in 1914 was accompanied by the establishment of a central body called the Nigerian council.” With Lugard the governor general, the council comprised twenty four of the most senior British officials in the country. The council included also twelve nominated unofficial, six of whom were British individuals representing various trading and commercial interests. The other six were Nigerians, namely, the sultan of Sokoto Emir of Kano, Alaafin of Oyo, Chief Dore Numa (Itsekiri) Messrs Richard Henshaw (calabar) and C. A. Sapara (Lagos).

The representation of Nigerians in the council stated above was just to fulfill all righteousness because they were in the minority and functioned as advisory body which was an appendage of the real executive. The nationalist agitation for peace and unity made the Lugard successor; sir High Clifford in 1919 to dissolve the council. This was replaced with a legislative council with the new constitution in 1922, which supported government administrative and fiscal policies. The elective principle included in the constitution gave room to the formation of the political parties. Between 1914 and 1938, the leading party was the Nigerian National 
Democratic Party (NNDP) founded by Herbert Macaulay who was normally referred to in Nigerian history as the father of Nigerian Nationalism.

As at the middle of 1930s, between 1931 and 1935 the educated elites were introduced to governance during the reign of Governor Donald Cameron, the Nigerians in the southern provinces could no longer be marginalized, hence peace and unity were promoted in the country.

According to kaita in Omoregie (2013) when he commented on the level of peace and unity that have existed in every sector of Nigerians economy and the British contribution to this, he said,

Since 1914 the British Government has been trying to make Nigeria into one country but the Nigeria people themselves are historically different in their backgrounds. In their religious beliefs and customs and do not show themselves any sign of willingness to unite ... Nigerian unity is only a British invention.

“Alhaji Sir Abubakar. Tafawa Balewa was reported by the Time Magazine of October 10,1960 to have said there was no basis for Nigerian unity and it was only a wish of the British” he also said concerning the contribution of the Lord Lugard to national unity that:

What is critical and important are the reasons Lugard gave in his dispatches. They are as follows he said the North is poor and they have no resources to run the protectorate of the North that they have no access to the sea, that the south has resources and they have educated people when the amalgamation took effect the British government sealed offs the Nouth from the North and between 1914 and 1960, that's a period of 46 years, the British allowed minimum contact between the North and the South because it was not in the British interest that the North be allowed to be polluted by the educated South.

Owolabi (2014) said:

Tracing the history back to the emergence of Nigerian nationalism would all admit that the British colonialism created Nigeria joining diverse peoples and regions in an artificial political entity. Sometimes, I wonder if the white man did an ethnographic research Nonetheless common sense should tell you that you don't cage cat and mouse in same place.

From the above quotations, one could realize that the colonial master created national unity through amalgamation for their own administrative convenience. A conversation between two Nigerian nationalists according to Owolabi who quoted John N. Paden in his book dedicated to the unity of Nigeria between Nnamdi Azikwe of NCNC and Ahmadu Bello of NPC

Azikwe said, “let’s forget our differences”, Bello said, “No, let us understand our differences. I am a Muslim and a Northerner. You are a Christian an Easterner. By understanding our differences we can build unity in our country.”

Owolabi (2014) commented on the above dialogue which bothers on most unity and peace in Nigeria and said:

It's quite unfortunate that after ninety eight years of amalgamation of the 484 ethnic groups and fifty two years of the country's independence we all still live in xenophobia. And the threat of schism is teaming the coat of nationhood apart. The pervading mood of fear has therefore made this questionable one nation bound in freedom, peace and unity. Is Nigeria one nation? Are we bound in freedom? Is there peace and unity? More also I beg to challenge the line of our anthem that puts 'peace' before 'unity' I don't think one can have peace without unity first. 


\section{The Picture Below Represent Nigerian Leaders Who Strove for Peace and Unity in Nigeria Before and After Independences}

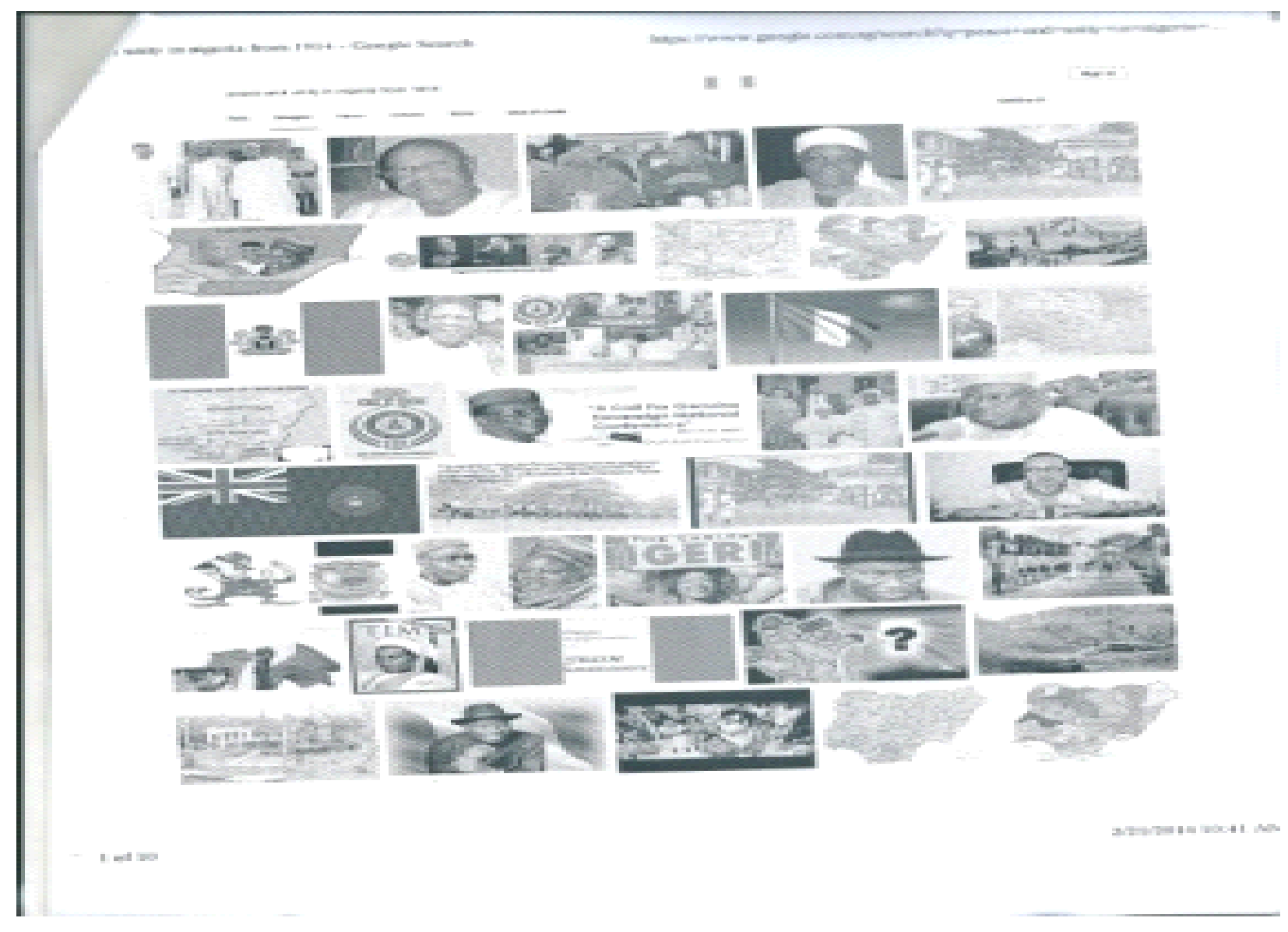

\section{Conclusion}

This paper concluded by saying that the period 1914 to 1938 in the history of Nigeria as it affected other countries of the world was a time of serious conflict among nations, a period when over five million people lost their lives in the first world war (WWI). The war was immediately followed by settlement of peace among the great and central powers of the world and this led to some economic recession that necessitated a scramble for African countries i.e. (Nigeria) for marketing of products of the Europeans and Americans and the need for human labour. In the struggle to maintain peace and unity at home education played a vital role to fit in, to the need of the period. Through advocacy, display of democracy by various unions and movements who fought for the fundamental human rights of Nigerians military training and preparation of citizens for political leadership and eventual national independence.

\section{Recommendations.}

The following recommendations are made for this paper, to improve peace moves and unity in Nigeria, especially in the education sector and also for future researchers; 
Nigerian Educational Research Development Council (NERDC) should formulate policies which will bring cohesion with a bid to balancing the gap between the Northern and Southern Nigeria:

Labour unions should resolve issues with the government on a round table conference and not through violence and strike actions i.e. Nigerian Union of Teachers (NUT) and Academic Staff Union of Universities (ASSU);

- the government should not mingle educational matter with politics;

- government at all levels should make adequate provision for education in the yearly budget and release fund as at when due for educational programmes;

- education personnel should be well remunerated for maximum encouragement and to enhance improved productivity through unity of purpose with government policies on education;

- the government should attend promptly to workers requests in order to avoid constant industrial actions;

- government should enforce strict compliance by the citizen on policy enacted on religious tolerance;

- modern infrastructural facilities to made available both in the institutions of learning and the society.

\section{References}

\section{Primary Sources}

Tigbiyele, E. A. (1970). National archives, Ibadan (NAI), On National Unity and Nigerian Foreign Policy Lagos: University at Lagos Continuing Education Centre, 1-3

National archives, Ibadan (NAI), (1979). The constitution of the Federal Republic Of Nigeria, F.G.P, 10-13

Bretton, H. L. (1962). National archives, Ibadan (NAI), “Power and stability in Nigeria: The politics of Decolonization” New York: Frederick A. Praeger, xii, 1, 10-13.

\section{Secondary Sources}

Aderemi, A. (2013). Nigeria: A complete Factfinder, “100 Years of Amalgamation” 9th Edition, 3-5.

Ajala, E. M. (2008). Peace Education. A Harbinger for conducive workplace environment in Boucoucalas, M \& Aderinoye, R. Education for Millenium Development, Spectrum Books Ltd \& Saferi Books, Ib (Export) Ltd. U.K. 145-152.

Aspespagh, R. (1996). Education for peace and culture in three decades at peace of around the world. An Anthology ed, New York, Carland, 1-2.

Reid, R. (2014). International Engagement with Africa, 1914-2014, International Affairs, internet. 147-160.

Embassy of Nigeria (1991). Nigeria Education, Washington, http://www.monarchy.com/history/nigeria/nigeria, 1-9.

Falola, T. (1999). Pre-Colonial Nigerian States Politics and Economy, http://www.onlinenigeria.com/mapethnic.asp on 21/2/2014, $17-27$.

Gbadamosi, L \& Jeyesimi, G. (2010). Studies in Educational Planning and Administration (SEPA) vol. 4, No.1 A Journal of the National Institute for Educational Planning and Administration (NIEPA), Nigeria, 59-66.

Watson, J. (1974). Success in Twentieth Century World Affairs, John Morray (Publishers) Ltd. Great Britain, London, 1-36.

Nigeria-Colonial Nigeria (1991) internet http://www.monarchy.com/history/nigeria/nigeria-colonalnigeriahtm\#s4ycieliob2fyl.99. 1.

Odunwobi, T. (2011). From Conguest to Independence: The Nigerian Colonial Experience, internet, 1-11.

Olaniyi, R. (2014). Approaching the study of Yoruba Diaspora in Northern Nigeria in the 20th Century, IFRA Special Research Issue, Vol. 2, http://books.opendition.org/ifra/919 1-17.

Osokoya, I. O. (2005). Female and Girl Child Education as a Development challenge in the Former British West African States, CISH 2005, University of Sydney, 1-4.

Peace Education from Wikepedia, the free encyclopedia, http://teacherswithoutborders.org/page/what-peace-education 1-5.

Osokoya, I. O. (2010). Teaching and Researching History in Nigeria, Laurel Educational Publishers Ltd. Ibadan, 82-84. 